\title{
Artigo
}

\section{Crise sistêmica, desordem mundial, financeirização e Estado: desafios e oportunidades para os países emergentes}

Systemic crisis, world disorder, financialization and the role of the State:

challenges and opportunities for emerging countries

\author{
Marcos Costa Lima \\ Professor do Departamento de Ciência Política \\ da Universidade Federal de Pernambuco \\ Coordenador do Núcleo de Estudos \\ e Pesquisas Regionais e do Desenvolvimento \\ marcoscostalima@terra.com.br
}

\begin{abstract}
Resumo: $\bigcirc$ trabalho está dividido em seis partes articuladas e, em nível mais geral, analisa o contexto macroeconômico e político mundial nos últimos trinta anos e aponta seus traços mais fortes. Na primeira parte, trabalha indicadores e as reflexões de Stiglitz e Krugman sobre o processo de ampliação da concentração de renda e riqueza no centro do sistema. Na segunda parte, introduz a discussão sobre o papel do Estado, apoiando-se nas contribuições de Polanyi, Harvey e Bourdieu, sugerindo a necessidade de se pensar conjuntamente o econômico, o político e o território, que conformam uma totalidade. Na terceira parte, discute o lugar dos países emergentes nesta nova configuração do capital mundial. Na quarta parte, com base no último livro do economista Deepak Nayyar, passa-se em revista a situação mundial em dois períodos históricos - 1850-1950 e 1950-2010. Aponta-se a grande divergência, sobretudo em termos de renda per capita, que se inicia no século XIX em detrimento da periferia. Na quinta parte do texto, chega-se então ao contexto econômico global recente e suas repercussões negativas sobre a renda dos trabalhadores. Finalmente, apresenta-se o quadro de desafios e oportunidades para o Brasil, nisto que chamamos de crise do sistema mundial.
\end{abstract}

Palavras-chave: crise sistêmica mundial; desigualdade; estado; países emergentes.

\footnotetext{
Abstract: The work is divided into six parts articulated and, more broadly, analyzes the macroeconomic context and political world in the past thirty years and points out its strongest traits. In the first part, it discusses indicators and reflections of Stiglitz and Krugman on the process of expanding the concentration of income and wealth at the center of the system. In its second part introduces the discussion about the role of the state, relying on contributions of Polanyi, Harvey and Bourdieu, suggesting the need to think together the economic, the political and the territory, which conform a whole. In part three, discusses the place of emerging countries
} 
in this new configuration of global capital. In the fourth part, based on the last book of economist Deepak Nayyar, passes in review the world situation in two historical periods - 1850-1950 and 1950-2010, pointing to a great divergence especially in terms of per capita income that begins in the nineteenth century at the expense of the periphery. In the fifth part, then it comes to the recent global economic context and its negative impact on the income of workers. Finally, the paper presents the framework of challenges and opportunities for Brazil, in the heart of the world crisis system.

Keywords: global systemic crisis; inequality; state; emerging countries.

\section{Estrutura e contexto}

O contexto macroeconômico mundial, nos últimos trinta anos, foi marcado por dez traços distintivos: i) Taxas muito baixas de crescimento do PIB, inclusive no Japão, que tradicionalmente serviu como "locomotiva" para o restante da economia mundial; ii) uma taxa de crescimento muito forte dos indicadores relativos ao valor nominal' dos ativos financeiros; iii) a limitação e redução das políticas de bem-estar social, associada à perda de regulação pela maioria dos estados nacionais; iv) altos índices de desemprego estrutural nos países da OCDE, associados a formas de emprego temporárias e com baixo nível de remuneração, provocando um aumento da pobreza nesses países; v) ampliação das desigualdades entre países ricos e pobres²; vi) uma conjuntura mundial instável, entrecortada por sobressaltos monetários e financeiros, com alto nível de contágio internacional (México, 1994; Malásia,1997; e a sequência que vai da Rússia à Argentina em 2001 e posteriormente a sub-prime em 2008); vii) uma deflação aberta e crescente entre os países industrializados, principalmente entre os países produtores de bens primários; e, finalmente, viii) a marginalização de regiões inteiras do globo com relação ao sistema de comércio internacional; ix) o surgimento da China como um possível novo centro sistêmico; x) o crescimento econômico mundial sendo puxado pelos países emergentes, mas já em esgotamento.

David A. Stockman³, que foi diretor do Office of Management and Budget de Ronald Reagan, afirmou no New York Times, em março de 2013, que ao longo dos últimos treze

Nominal porque sobre elas incide um componente fictício, mais ou menos importante, segundo a natureza dos ativos.

$2 \quad$ PNUD (1999): "Em 1820, a renda per capita dos países mais ricos era 3 vezes maior do que os mais pobres. Em 1870 era 7 vezes maior; em 1913 era 11 vezes maior e em 1960, 30 vezes maior. Em 1997, um quinto da população mundial que vivia nos países mais ricos era 74 vezes mais rica que um quinto da população nos países mais pobres".

3 Stockman, David A. (2013), The Great Deformation. The Corruption of Capitalism in America. New York: Public Affairs Book. 
anos o mercado de ações caiu duas vezes, provocando graves recessões. As famílias americanas perderam um trilhão de dólares na crise dot.com, em 2000, e mais de sete trilhões de dólares durante a crise subprime de 2007. Nesse período, o número de auxílios-refeição e os benefícios por invalidez mais que dobraram, alcançando 59 milhões de pessoas, ou um em cada cinco americanos. Estes números assustadores crescem em relevância quando sabemos que a dívida pública dos EUA alcançou 56 trilhões de dólares no início deste ano4.

No tempo em que Alan Greenspan esteve à frente do Federal Reserve - agosto de 1987 a janeiro de 2006 - se deu o maior equity boom do país, com o mercado de ações crescendo cinco vezes entre a crise de 1987 e aquela da dot.com em 2000.

A farra rentista terminou com a bancarrota do grupo Lehman Brothers, em setembro de 2008. Stockman nos diz que

Washington, com a arma de Wall Street virada para sua cabeça, foi ao socorro dos protagonistas desta bagunça financeira, imprimindo dinheiro para o resgate de grandes empresas em pânico, o que segundo ele, consistiu no singular e mais vergonhoso capítulo da história financeira americana. ${ }^{5}$

O fantástico crescimento da construção civil e dos investimentos em infraestrutura ao longo dos últimos 15 anos na China vem arrefecendo. O Brasil, a Rússia, a Índia, a Turquia e a África do Sul, bem como todas as outras nações de renda média em crescimento, não podem compensar a queda da demanda.

Paul Krugman', em seu livro publicado no Brasil em 2010, apontava que não houvera um grande aumento da desigualdade nos Estados Unidos até a década de 1980. Para o economista, a reviravolta se deu a partir daí, quando os vencedores foram uma pequena elite de 1\% no topo da distribuição de renda.

O Secretário do Trabalho no período Bill Clinton, Robert Reich?, escreveu sobre as dimensões históricas da ampliação das desigualdades nos EUA:

4 A questão da saúde nos EUA é um aspecto relevante da crise que vive o país. São 50 milhões de pessoas que hoje não dispõem de seguro saúde, ou seja, 1 em cada 6 pessoas. Cf. Louis Gill (2012), "Après cinq ans de crise". Carré Rouge, n. 47, été, p. 46.

5 STOCKMAN, David A. "State-Wrecked: the corruption of capitalism in America". The New York Times, 30/3/2013, pp. 15-16 e 59.

$6 \quad$ KRUGMAN, Paul (2010). A consciência de um liberal. Rio de Janeiro: Record.

7 REICH, Robert (2010). The Root of Economic Fragility and Politcall Anger, Huffington Post, 13 July 2010. 
Em 1928 o 1\% mais rico entre os americanos detinha 23,9\% do total da renda nacional. Após este período, esse valor declinou substantivamente. As reformas do New Deal, seguidas pela Segunda Guerra Mundial, o Gl Bill and the Great Society ${ }^{8}$ expandiram o círculo de prosperidade. Por volta do final de 1970 o 1\% mais rico recebia não mais que 8 a 9\% do total anual dos rendimentos nacionais. Depois disso, a desigualdade começou a retomar e a renda reconcentrou no topo. Em 2007 o 1\% mais rico retomaram a posição de 1928, com 23,5\% do total.

Joseph Stiglitz", em seu último livro sobre o crescimento da desigualdade de renda e da riqueza nos Estados Unidos nos últimos trinta anos, é ainda mais incisivo do que Krugman. Diz Stiglitz logo no prefácio, e em tom quase bombástico, que "existem momentos na História quando as pessoas em todo o mundo parecem levantar-se para dizer que algo está errado". Seus dados são contundentes sobre os efeitos de políticas econômicas que geraram desigualdade de renda e riqueza nos Estados Unidos após os anos 1980, quando 1\% das maiores rendas entre os americanos recebia apenas 12\% da renda nacional. Em 2007, a média dos rendimentos, retirados os impostos, do 1\% mais ricos era de USD 1.3 milhão, enquanto os rendimentos dos 20\% na base da pirâmide só representava USD 17.800. Ou seja, o 1\% mais ricos ganhavam em uma semana 40\% a mais do que 1/5 mais pobre durante todo o ano. Ainda nesse mesmo ano, a fatia de 0,1\% dos domicílios mais ricos do país tinha uma renda 220 vezes maior do que a média dos $90 \%$ na base.

Quando olhamos para a Europa a situação é ainda mais dramática. Segundo o Fundo Monetário Internacional, 61 países voltaram ao nível do Produto Interno Bruto de 2007, entre os quais 22 dos 27 países da União Europeia, e 6 dos 7 países do G7, à exceção da Alemanha. Em 10 dos 25 países da OCDE, os salários reais (corrigidos pela alta dos preços) de 2010 eram inferiores aos níveis de 2007. Havia desemprego de 24,3\% na Espanha e de 21,7\% na Grécia, em abril de 2012, sendo de 51,5\% para os menores de 25 anos de idade. A Alemanha conseguiu se distinguir dos demais países europeus graças a políticas de desregulamentação do mercado de trabalho e da proliferação do

8 O Servicemen's Readjustment Act, de 1944, conhecido por Gl Bill foi uma lei que beneficiou os soldados vindos da guerra com uma série de vantagens, como hipotecas favoráveis, empréstimos a baixos juros para o início de negócios, bolsas para educação vocacional, curso secundário e faculdade e compensação por desemprego. As medidas chegaram a beneficiar um total de 6.6 milhões de pessoas.

$9 \quad$ SITGLITZ, Joseph E. (2012). The Price of Inequality. How today's divided society endangers our future. New York: W. W. Norton \& Company. P. IX, 2-3. 
trabalho flexível e precário, que deram lugar aos baixos salários. Nesse país, o emprego em tempo integral caiu de 29,3 para 23,9 milhões entre 1991 e 2001, enquanto crescia o número de empregos em tempo parcial, que aumentou de 5,7 para 12,5 milhões ${ }^{10}$.

Conforme Dani Rodrik", mesmo na Europa, onde as instituições regionais são relativamente fortes, o interesse nacional e os políticos nacionais, em grande medida na pessoa da chanceler alemã, Angela Merkel, têm dominado a definição de políticas. Segundo ele, se a chanceler Merkel tivesse se mostrado menos apaixonada pela austeridade com relação aos países endividados da Europa e se tivesse conseguido convencer os seus eleitores da necessidade de uma abordagem diferente, a crise da zona do euro teria tido contornos bastante diferentes.

Para François Chesnais'12, a situação de conjunto da economia mundial é marcada pela incapacidade do "capital" (os governos, os bancos centrais, o Fundo Monetário Internacional e os centros privados de centralização e de poder do capital tomado coletivamente) de encontrar, ao menos por agora, os meios de criar uma dinâmica diferente. A crise da zona do Euro e seus impactos sobre um sistema financeiro opaco e vulnerável são uma das expressões. Esta incapacidade não é, para o economista francês, sinônimo de passividade política. Ela significa simplesmente que a burguesia está se movendo, cada vez mais, pela vontade única de preservar a dominação de classe em toda sua nudez. Portanto, esse projeto tem implicações políticas ainda mais graves para os trabalhadores, pois ele é acompanhado pelo endurecimento do caráter pró-cíclico das políticas de austeridade e privatização, e contribui para a ocorrência de uma nova recessão, que está em marcha.

Todo o impacto desta crise refletiu diferentemente em regiões periféricas e, em especial, em algumas economias emergentes, em particular na China, Índia e Brasil. Neste trabalho daremos ênfase ao comportamento brasileiro no sentido de enfrentar a crise mundial e com relação aos tópicos a saber: formas atuais de manifestação da crise no Brasil; políticas públicas para um desenvolvimento sustentável; sustentabilidade urbana e rural; e a crise energética e ambiental. Em todos estes pontos, há evidências de um enfrentamento inadequado por parte do atual governo brasileiro, sobretudo no que

GILL, Louis (2012). Aprés cinq ans de crise. Un état des lieux sommaire. In: Carré Rouge, n. 47-été. RODRIK, Dani (2012). "O renascer do Estado-nação”, publicado em Project Syndicate, 13/3/2012.

12 CHESNAIS, François (2011). Aux racines de la crise économique mondiale. Carré Rouge, n. 46, décembre, pp. 7-17. 
concerne ao aumento da dívida pública; o atrelamento das exportações brasileiras às commodities agrícolas e minerais, com efeitos graves sobre a baixa empregabilidade no setor de agrobusiness, mas também com relação ao meio ambiente. O importante fenômeno da "reprimarização"; o caos urbano, que provocou mobilizações intensas ao longo de 2013; e a questão energética, um dos fatores de importação de capital e de venda de ativos ao capital internacional. Finalmente, como estratégia geral, o foco intenso do governo numa visão intitulada de neodesenvolvimentista, tem levantado sérias dúvidas sobre a deterioração ambiental. Os aspectos mais positivos estão por conta da consolidação do processo democrático e de políticas sociais de distribuição, com respostas positivas na educação, na saúde e no consumo alimentar das camadas populares, mas que não são suficientes para estruturar um padrão de desenvolvimento alternativo para o país e tem provocado o desgaste dos processos de representação de política formais.

\section{O Estado}

Em sua obra prima sobre o capitalismo a partir da Revolução Industrial e seus desdobramentos no século XIX, Karl Polanyi ${ }^{13}$ afirma que esse momento de ruptura que surge a partir da Inglaterra provocou uma desarticulação social de imensas proporções; segundo ele, o "problema da pobreza era apenas o aspecto econômico desse acontecimento". Polanyi alertava para o perigo de se deixar a economia de mercado desenvolver-se segundo suas próprias leis, o que para ele acarretaria grandes e permanentes males. O historiador de origem húngara nascido em Viena põe em relevo o momento crucial na história da civilização, quando o homem e a natureza são transformados em mercadoria. "Se este processo se organizar através de um mecanismo autorregulador de permuta e troca, então o homem e a natureza têm que ingressar na sua órbita, têm que se sujeitar à oferta e à procura, isto é, eles passam a ser manuseados como mercadorias, como bens produzidos para a venda"14.

Ele desenvolve seu argumento evidenciando qual o papel do Estado na estruturação do "moinho satânico":

13 POLANYI, Karl (2000). A grande transformação. As origens da nossa época. Rio de Janeiro: Contraponto, p. 157.

14 Id. ibid., p. 162. 
Não havia nada natural em relação ao laissez-faire; os mercados livres jamais poderiam funcionar deixando apenas que as coisas seguissem o seu curso. Assim como as manufaturas de algodão - a indústria mais importante do livre comércio foram criadas com a ação de tarifas protetoras, de exportações subvencionadas e de subsídios indiretos dos salários, o próprio laissez-faire foi imposto pelo Estado ${ }^{15}$.

David Harvey ${ }^{16}$ reforça o entendimento de Polanyi. Para ele o Estado sempre jogou um papel central na acumulação primitiva, sempre utilizando seus poderes não apenas para forçar a adoção de arranjos institucionais capitalistas, mas também para adquirir e privatizar ativos, como base original para a acumulação de capital. E por certo, quando se tratou de luta por hegemonia, colonialismo ou política imperial, ou ainda sobre aspectos mais mundanos das relações internacionais, o Estado tem sido e continua sendo um agente fundamental na dinâmica do capitalismo global. Como geógrafo, e inspirado por Lefebvre, Harvey aprofunda as dimensões territoriais do Estado, mas abre o leque dos tipos de poder que afloram em suas especificidades regionais, subnacionais e até em grandes cidades, onde o poder político nos governos territoriais tem uma variedade de escalas geográficas e constitui uma hierarquia ordenada, onde o processo de acumulação acaba por acontecer. Ou seja, existe uma produção capitalista do espaço que gera desenvolvimentos desiguais. Vantagens locacionais que jogam um papel tão importante ou mesmo que concorrem para as vantagens tecnológicas. As vantagens competitivas tendem, dentro dessas estruturas espaciais, a impelir a busca por lugares onde os custos são mais baixos e os lucros, maiores.

Daí a necessidade de pensar conjuntamente o político, o econômico e o territorial (que engloba o ambiental) como partes articuladas. As categorias analíticas da ciência política, como o Estado, nas suas funções de múltiplas determinações, ou as relações internacionais, entendidas enquanto relações de rivalidade, conflito e cooperação entre Estados, marcadas entre outras questões, por profundas assimetrias na capacidade de certos Estados em influenciar a conduta interna de outros, notadamente no domínio-chave das regras, das instituições e da política econômica, enfim aquelas, certamente, do movimento de valorização do capital em suas diferentes formas.

15 Id. ibid., p. 170.

16 HARVEY, David (2005). The New Imperialism. Oxford University Press, pp. 91-93. 
Pierre Bourdieu" publicou em 1998 uma entrevista sob o sugestivo título de "A mão esquerda e a mão direita do Estado". O sociólogo, em crítica velada à metáfora da mão invisível, torna concreta a "manipulação" do Estado. Diz ele: "O estado se retirou de um certo número de setores da vida social que eram sua incumbência e pelos quais era responsável". O autor se refere aos cortes de gasto para setores coletivos e sociais como escolas públicas, hospitais e habitação, os serviços públicos em geral oferecidos à maioria da população, a começar pelo salário dos funcionários. Mas podemos alargar a questão, apontando o abandono das aposentadorias, quando o sistema de cotização é abandonado e dá lugar aos Fundos de Pensão, que jogam um papel decisivo na financeirizaçao ${ }^{18}$. Bourdieu aponta um fator importante, que nunca é demais enfatizar: o campo simbólico. Diz ele:

A televisão contribuiu, sem dúvida, tanto quanto as propinas, para a degradação da virtude civil. Ela chamou e promoveu ao primeiro plano da cena política e intelectual indivíduos vaidosos, preocupados em exibir-se e valorizar-se, em contradição total com o devotamento obscuro ao interesse coletivo que caracterizava o funcionário ou militante (...). Em suma, a grande corrupção, cujo desvelamento provoca escândalo porque revela a defasagem entre as virtudes professadas e as práticas reais, é apenas o limite de todas as pequenas "fraquezas" comuns, ostentação de luxo, aceitação açodada dos privilégios materiais ou simbólicos ${ }^{19}$.

Mas, para além destas contribuições, Bourdieu nega um sofisma que foi amplamente veiculado pela mídia global, a saber, de que o Estado deveria ser mínimo, para não atrapalhar a exuberante dinâmica do capital. Na verdade, o Estado nitidamente tem operado como facilitador e gerenciador do grande capital, tem usado sistematicamente a sua "mão direita".

Há uma reflexão de Harvey ${ }^{20}$ que pode aqui ser útil, quando o geógrafo afirma que as condições preferidas para a atividade capitalista é aquela de um estado burguês no qual as instituições e as regras do contrato (inclusive aquelas do trabalho) são

17 BOURDIEU, Pierre (1998). Contrafogos. Táticas para enfrentar a invasão neoliberal. Rio de Janeiro: Zahar Editora, pp. 9-19.

18 SERFATI, Claude (2014). The New Configuration of The Capitalist Class. In: Socialist Register, p. 145: foi calculado que ao final de 2011, a gerência dos fundos globais está a gerir \$132 trilhões de ativos, dos quais \$31.5 trilhões vinham dos Fundos de Pensão, um volume não muito distante do total do volume total de dinheiro proveniente da riqueza privada (USD 42 trilhões).

19 BOURDIEU, op. cit., p. 13.

20 HARVEY, op. cit., p. 91. 
legalmente garantidas, e onde enquadramentos de regulação são construídos para conter conflitos de classe e para arbitrar entre os reclamos de diferentes facções do capital (comerciantes, financistas, industriais, setor agrário). A assertiva de Harvey é válida em termos, pois nos últimos trinta anos, digamos, o sistema capitalista cortou todas as suas amarras legais, que no mais das vezes funcionam apenas como uma armadilha. Se assim não fosse, como poderíamos explicar a proliferação de paraísos fiscais ${ }^{21} \mathrm{em}$ todo o mundo, que são justamente os albergues do capital-dinheiro em busca de maior rentabilidade, ou ainda toda a alavancagem que foi permitida aos bancos, tornados conglomerados financeiros, agências financeiras e de securitização, sem falar na maquiagem que foi realizada nos centros sistêmicos, para encobrir as dificuldades contábeis de grandes empresas transnacionais? Não me refiro aqui à chamada "economia do crime", mas àquela praticada pelos grandes agentes legais do capital.

François Chesnais nos ajuda a resolver a questão, quando afirma que só entenderemos o funcionamento da economia mundial se nos confrontarmos com um conjunto de "relações que fazem um sistema", sendo que tanto a marginalização quanto a exclusão social são nada mais do que formas específicas da relação como um todo. ${ }^{22}$ Os sistemas de relações interestatais que dão suporte à mundialização do capital devem ser abordados como elementos de uma totalidade, das diferenciações que se estabelecem no interior mesmo dessa unidade:

A diferenciação e a hierarquização da economia-mundo contemporânea de dimensão planetária resultam tanto de operações do capital concentrado quanto das relações de dominação e de dependência políticas entre estados, cujos papéis não são de nenhum modo reduzidos, mesmo se os mecanismos desta dominação tenham se modificado23.

21 Claude Serfati (op. cit., p. 140) fala do extenso desenvolvimento de centros financeiros offshore, mais de oitenta em todo o mundo. Esses centros financeiros recebem fundos em moeda estrangeira de não residentes que ali são depositados para depois serem canalizados, através de intermediários financeiros offshore, aos tomadores de empréstimo, também não residentes; permitem a fuga do controle e regulamentos dos Estados de origem do investidor (individual ou institucional); são parte de redes de operações financeiras protegidas pelo anonimato; e também constituem parte de redes financeiras de lavagem de dinheiro.

22 COSTA LIMA, Marcos (2014). A economia política de François Chesnais: ciência e luta. In: CASSIOLATO, José; MATOS; Marcelo; LASTRES, Helena (orgs.). Desenvolvimento e mundialização. O Brasil e o pensamento de François Chesnais. Rio de Janeiro: E-papers.

23 Chesnais, François (1997), op. cit., p. 64. 
Esse regime de acumulação mundializado, com predomínio do financeiro, resulta tanto da política quanto da economia. E é o neoliberalismo que quer fazer crer, propaga e difunde a ideia segundo a qual o Estado é exterior ao mercado. Diz ele que o triunfo do mercado não teria sido possível sem as interferências políticas que provêm dos mais poderosos Estados capitalistas, como os do G7. "Foi através de uma articulação estreita entre a política e a economia que as condições para a emergência dos mecanismos e das configurações dominantes desse regime foram criadas ${ }^{24}$. Essa ofensiva política, como conhecemos, surgiu ao final dos anos 1970, na Inglaterra, e no início dos 1980, com Reagan nos EUA.

A figura do Estado, como foi antevista por James O'Connor25, passa a sofrer um forte ataque midiático, sempre no sentido de proclamar a sua inoperância, a sua falta de agilidade e a atitude imprevidente de fazer gastos além de suas possibilidades. Estabelecia-se assim o "mantra" propagado por toda grande imprensa e propulsado pelas escolas de administração e economia dos Estados Unidos, na defesa arraigada do mercado.

Em resumo, essa ofensiva consistiu precipuamente em quebrar o conjunto das instituições e das relações sociais que constrangiam o capital. Essas instituições e suas relações tinham capacidade para frear a liberdade de ação do capital, asseguravam aos assalariados os elementos de defesa contra seus empregadores, garantiam o pleno emprego no período chamado keynesiano e uma proteção social para a maior parte da população, ao menos no centro do sistema.

Esse conjunto de fatores, que estabelecem o sistema, não é capaz de reduzir ou diluir o papel dos Estados nacionais, nem tampouco das relações de dominação e de dependência política que se estabelecem. Muito pelo contrário, acentuam a hierarquização entre países, ao mesmo tempo em que redesenham uma nova configuração. No centro e tendo lugar central, os Estados Unidos da América e os países da Tríade ou a eles associados - mesmo que de forma subordinada - são os que participam dos circuitos de valorização do capital por um lado. Por outro, os países que sofrem a dominação do grande capital-dinheiro, das inovações tecnológicas e das patentes associadas, cujos governos ou sucumbem ao cânone dos estados hegemônicos, ou devem sofrer

$24 \quad$ Id. ibid., p. 65.

25 O'CONNOR, James (1976). The fiscal Crises of the State. New York: St Martin's Press. 
ameaças pela rebeldia. Todo esse processo, que se acentua a partir dos anos 1980, repousa sobre as transformações da "relação salarial", no forte agravamento da taxa de exploração (níveis salariais, duração dos contratos, flexibilização do emprego e das condições de trabalho nas empresas), que são as características fortes da globalização do trabalho e do Consenso de Washington.

\section{Os países emergentes}

Repercussões em escala planetária vêm afetando com maior ou menor intensidade todas as regiões e sociedades mundiais e ainda é cedo para indicar com certeza quando será superada. Os problemas têm se acumulado, desde aqueles diretamente relacionados ao sistema econômico até os relacionados ao meio ambiente ou, ainda, os sociais, pela incapacidade de resolver as questões relativas ao bem-estar de grandes contingentes populacionais, dispersos nas sociedades mundiais e que ainda sofrem de privações intensas, marcados pela fome, pobreza, ausência de perspectiva para os jovens, falta e desigualdade na esfera do emprego, em que pese uma incontestável revolução tecnológica e um avanço nos domínios do conhecimento e da ciência'26.

As respostas à crise, por parte dos Estados que lideram a governança mundial, nos fazem pensar sobre o futuro do sistema mundial, pois nenhuma mudança efetiva foi realizada para conter a dinâmica perversa estabelecida a partir das finanças mundiais e da especulação rentista. Os governos dos países centrais se valeram das intervenções keynesianas tópicas, injetando capital, sobretudo nas grandes corporações ameaçadas, sem grandes interrogações sobre o paradigma no qual estamos envolvidos, pois estão convictos, em sua naturalização do problema, que logo o equilíbrio será restabelecido (os neoclássicos) e estão confiantes na assertiva "to big to fail".

Ao mesmo tempo em que ocorreu a crise, a China vem se consolidando como um grande player internacional. O modelo ali implantado, desde 1978, baseado em políticas intensivas de exportação e investimentos pesados em infraestrutura - estradas, ferrovias, trens de alta velocidade, metrôs, pontes, portos - associou-se ao capital internacional - principalmente do Japão, Coreia, Estados Unidos e União Europeia - fazendo do

26 COSTA LIMA, Marcos (2011). Região \& desenvolvimento no capitalismo contemporâneo. São Paulo: UNESP, pp. $1-2$. 
país um forte candidato a disputar hegemonia com os EUA e se portar como a segunda economia mundial em termos de Produto Interno Bruto.

A tabela a seguir é importante por salientar o papel do capital internacional produtivo na China, sobretudo produzindo para o mercado mundial e oportunizando as vantagens do país asiático com relação aos salários mais baixos, uma mão de obra disciplinada e qualificada e também da infraestrutura rodoferroviária e de portos instalada.

Tabela 1: Decomposição da estrutura de propriedade das firmas nas exportações chinesas em 2005.

\begin{tabular}{|l|l|l|l|l|l|}
\hline & All firms & $\begin{array}{l}\text { Foreign- } \\
\text { owned }\end{array}$ & $\begin{array}{l}\text { Joint } \\
\text { ventures }\end{array}$ & $\begin{array}{l}\text { Private } \\
\text { domestic }\end{array}$ & $\begin{array}{l}\text { State- } \\
\text { owned }\end{array}$ \\
\hline Exports & $100 \%$ & $50.4 \%$ & $26.3 \%$ & $13.1 \%$ & $10.3 \%$ \\
\hline
\end{tabular}

Fonte: Manova e Zhang ${ }^{27}$ (2008)

Em 2001, o chefe economista do Goldman Sachs liderou estudo apontando a dinâmica econômica de países como Brasil, Rússia, Índia, China e, posteriormente, África do Sul - BRICS, concluindo que em 2050, a China já superaria a principal economia mundial e que os demais também subiriam ao topo do ranking, situando-se entre as economias mais ricas do planeta. Outros analistas, a exemplo de Deepak Nayyar28, além de confirmar os números e as análises de Jim O’Neil, acrescentaram que a mudança de posições na hierarquia econômica em favor dos BRICS se faria em menos tempo, antecipando os resultados esperados já para 2030.

Por certo estas análises e seus desdobramentos foram impactados pela crise da sub-prime a partir de 2008, não obstante o crescimento chinês ter se mantido robusto até o presente, comparativamente aos resultados dos países centrais. De todo modo, a China inicia uma transformação forte do sentido de sua economia para o mercado interno.

27 MANOVA, K e ZHANG, Z. (2008). "China's exporter and importer firms products, and trade partners." Unpublished manuscript. Dept. of Economics, Stanford University, June. Apud: PALLEY, Thomas I. (2013). Gattopardo economics. The crisis and the mainstream response of change that keeps things the same. Working Paper, april, n. 112. Macroeconomic Police Institute.

28 NAYYAR, Deepak. Developing Countries in the World Economy: The Future in the Past? WIDER Annual Lecture 12, UNU-WIDER, Helsinki, 2009. 
Há muito a se discutir, pois a complexidade das transformações nos últimos dez anos tem grande abrangência e precisa ser analisada em diversos setores: financeiros, industriais, tecnológicos, territoriais, ambientais e sociais. O Brasil nos últimos dez anos também foi impactado pela dinâmica mundial e, em particular, pelo nível da atividade econômica na China. Por um lado tivemos ganhos sociais substantivos em políticas públicas, que foram capazes de reduzir a mortalidade infantil, reduzir o analfabetismo, ampliar o número de alunos nos cursos secundário e terciário, e, por outro, também conseguimos ampliar o nível de emprego e aumentar o poder de consumo das camadas populares, quando o centro do sistema se encontra em crise e estagnação e fazendo políticas em direção contrária.

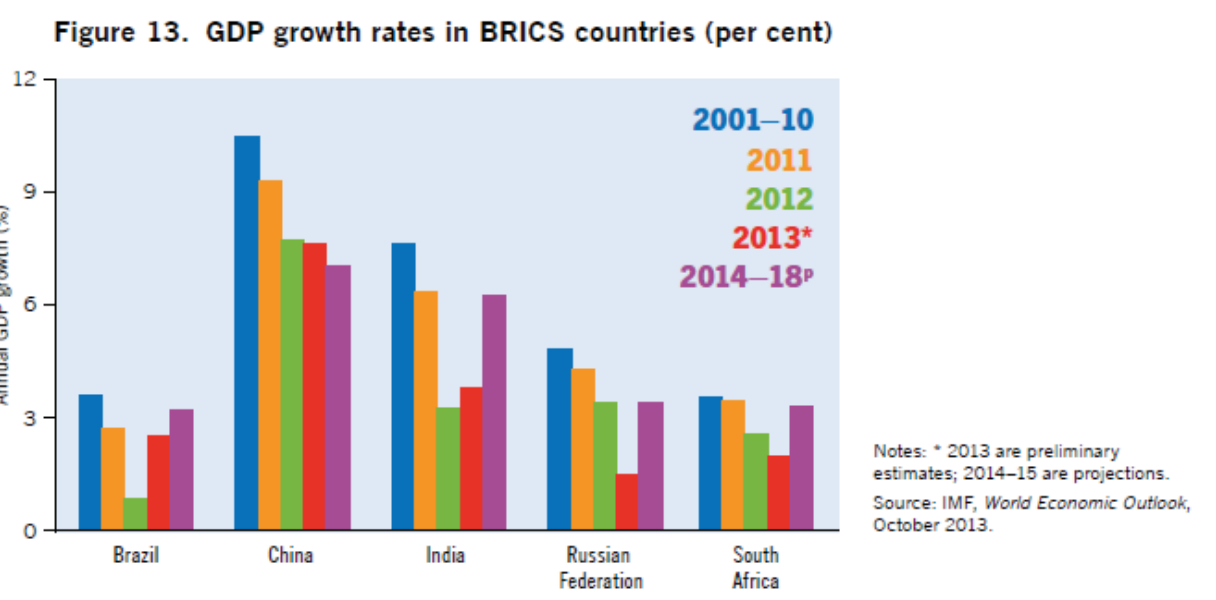

Como foi assinalado por Marcos Costa Lima²9, a participação da China nas importações brasileiras de vários produtos industrializados disparou nos últimos anos, atingindo em alguns casos proporções muito elevadas; a exemplo da compra de celulares ao país asiático, que entre janeiro e setembro de 2011 representou 70\% do total importado desses bens. No mesmo período, 72\% dos tecidos de fibras têxteis, 81\% dos brinquedos, 84\% dos aparelhos eletromecânicos de uso doméstico, além de 53\% das máquinas automáticas para processamento de dados vieram da China. Hoje, a China deslocou os EUA como nosso principal parceiro comercial, mas esse trade-off em certa medida reproduz um padrão de país rico x país pobre.

Só para dar uma medida do que representou o grande crescimento das exportações brasileiras para a China, estas passaram, entre 2000 e 2010, de US\$ 1,1 bilhão para

29 COSTA LIMA, Marcos (2012). O Brasil e os BRICS e a agenda internacional. In: FUNAG (Org.). O Brasil e os Brics e a agenda internacional. Brasília: Funag. p. 162. 
US\$ 30,8 bilhões. No sentido contrário, as importações brasileiras da China cresceram de US\$ 1,2 bilhão para US\$25,6 bilhões no mesmo período.

A China vem fazendo avanços substantivos na inovação e no conhecimento e tem feito crescer esses investimentos de US\$ PPP 39,2 bilhões para US\$ PPP 102,4 bilhões no mesmo período. Tudo isso aponta para uma assimetria que tem tendência a ser reforçada, em curto e médio prazos, em prejuízo do Brasil, que passa a vender commodities em troca de produtos industriais com aporte tecnológico intensivo.

Poderíamos aprofundar essas assimetrias, mas cabe chamar a atenção para o fato de que, estrategicamente, o Brasil necessita aprofundar seu conhecimento sobre a China em diversos setores e políticas, para poder compartilhar uma relação, não apenas comercial, mas política e diplomática, mais segura e propositiva.

\section{A situação mundial em dois períodos: 1850-1950 e 1950-2010}

O economista indiano Deepak Nayyari3o recém publicou um livro que tem a qualidade de analisar a evolução histórica dos países desenvolvidos na economia mundial em um amplo contexto macroeconômico. Com base nas estatísticas formuladas por Angus Maddison"11, entre outros, na comparação que fez sobre os níveis de PIB per capita entre países desenvolvidos e em desenvolvimento, Nayyar estabelece três grandes períodos históricos, sendo o primeiro do ano 1000 a 1820, o segundo de 1820 a 1950 e o terceiro de 1950 os dias atuais, grosso modo incluindo as regiões no Ocidente, na Ásia, na África e América Latina e, quando possíveis as previsões, abre os dados para o Japão, a China e a Índia. No primeiro período aponta o nivelamento entre as regiões mundiais em torno do PIB, para em seguida evidenciar o declínio das hoje tidas como regiões periféricas vis-à-vis, sobretudo, à Europa, quando os efeitos da revolução industrial aí começam a estabelecer uma divergência que se acentua e ganha velocidade. No terceiro momento, que engloba o período 1950 a 2010, para ele aparece o fenômeno do "catch up". Aqui, o autor aprofunda as possibilidades e os constrangimentos tanto para

30 NAYYAR, Deepak (2013). Catch up. Developing Countries in the World Economy. Oxford University Press.

31 MADDISON, Angus (1983). A comparison of levels of GDP per capita in Develop and Developing Countries, 1700-1980. Journal of Economic History, 43, pp. 27-41. 
o centro como para a periferia destas transformações e especula sobre as alterações no contexto internacional.

Para Deepak, mil anos atrás, a Ásia, África e América do Sul, juntas, contavam com mais de $80 \%$ da população e do produto mundiais, o que se fazia, basicamente, pela China e Índia. Esse predomínio perdura até 1500 quando têm início as mudanças, que passam a surgir no início do século XVI até o final do XVIII. O processo colonial foi ponto crítico da mudança, com a expansão mercantil e as mudanças políticas, sociais e institucionais na Europa. Mas mesmo nesse período as semelhanças entre a Europa e a Ásia eram mais fortes que as dessemelhanças, pois em 1820, portanto menos de duzentos anos atrás, a Ásia, a África e a América do Sul ainda contavam com quase três quartos da população mundial e em torno de dois terços da renda mundial. A participação da China e Índia, juntas, era de 50\%, mesmo em $1820^{32}$.

Segundo o economista indiano, as dramáticas transformações da economia mundial começaram em torno de 1820 e essa divisão geográfica no mundo acaba por se tornar uma divisão ou ruptura econômica. A partir daí, diz ele:

A relevância econômica da Ásia, África no produto mundial e América Latina testemunham uma queda abrupta, de modo que, em torno de 1950, havia uma pronunciada assimetria entre sua participação na população mundial, então de dois terços (2/3) do total e uma participação na renda mundial de um quarto (1/4). Em agudo contraste e no mesmo período, a Europa, a América do Norte e o Japão ampliaram sua participação na população mundial de um quarto(1/4) para um terço (1/3), e em termos de renda mundial, de um pouco mais de um terço (1/3) para quase três quar$\operatorname{tos}(3 / 4)$.

A grande divergência em renda per capita foi, portanto, a realidade. E em um período de 130 anos, de 1820 para 1950, como percentagem do PIB per capita, a América Latina caiu de três quintos (3/5) para dois quintos (2/5), na África, de um terço (1/3) para um sétimo (1/7), e na Ásia, de metade para um décimo (1/10)33.

Em termos de produção manufatureira, a participação da Ásia, África e América Latina, basicamente centrada na China e na Índia, entrou em colapso, baixando de 60\%

32 NAYYAR, Deepak (2013), op. cit., p. 174.

33 Id. ibid., p. 174. 
para 7,5\%, ao passo que a participação da Europa e Estados Unidos da América e Japão saltou de 40\% para 92,5\%, permanecendo nesse patamar até 1950.

Para Deepak, a industrialização da Europa Ocidental e a desindustrialização da Ásia ao longo do século XIX representavam os dois lados da mesma moeda.

É a partir daí que se configura a forte preponderância da Europa e dos EUA como exportadores de produtos industriais especializados e o "resto" do mundo como produtor de commodities. Ao mesmo tempo, de 1850 a 1950 as três regiões periféricas passam, pela via do comércio, dos investimentos e da imigração a serem progressivamente integradas à economia mundial, consolidando ainda uma particular divisão internacional do trabalho entre países que reforçaram as "trocas desiguais" ${ }^{34}$, com fortes tendências ao desenvolvimento desigual.

Finalmente, de 1950 a 2010, em termos das estatísticas de Maddisson, baseadas em PPP, a participação dos países desenvolvidos no produto global parou de cair, a partir de 1960, quando saem de um mero um quarto (1/4) para atingir metade (1/2) em 2008. A divergência em termos de renda percapita parou de aumentar em 1980 e foi seguida de uma lenta convergência daí em diante. Entre 1970 e 2010, a participação dos países em desenvolvimento no PIB mundial dobrou de um sexto (1/6) para um terço (1/3), mesmo que o PIB per capita tenha tido um alteração muito pequena, de um quatorze avos (1/14) para um onze avos $(1 / 11)^{35}$.

Por certo, essas agregações estão vinculadas ao período keynesiano do pós-guerra, quando boa parte dos países emergentes passou a construir seus parques industriais, através de políticas de substituição de importações. Contudo, convém assinalar que, a partir dos regimes ditatoriais na América Latina e das políticas de crescimento baseadas em poupança externa, essa região entra numa espiral de endividamento e políticas de ajuste monetário, que agravaram duramente as condições econômicas e sociais de seus países, o que não ocorreu na Ásia. Contudo, durante o período 1981-2008, as taxas de crescimento dos periféricos passaram quase a duplicar aquelas nos países industrializados. A participação dos periféricos no comércio de mercadorias, exportações e importações mais que duplicou, de menos de 20\% em 1970 para mais que 40\% em 2010. Em termos da produção industrial, a participação dos periféricos saltou de um doze avos

34 PREBISH, Raúl (1968). Dinâmica do desenvolvimento latino-americano. Rio de Janeiro: Fundo de Cultura. pp. 94-196.

35 NAYYAR, Deepak (2013), op. cit., p. 175. 
(1/12) para um terço (1/3) em preços constantes. Da mesma forma, sua participação nas exportações mundiais de manufaturas, em preços correntes, passou de um quatorze avos (1/14) para dois quintos (2/5), em grande medida devido ao desempenho da China, o que o autor intitula de "dramáticas transformações"36.

Deepak Nayyar considera acertadamente que o catch up que vem se cristalizando é necessário, mas não suficiente para melhorar as condições de vida da maioria das populações dos países periféricos. Mantêm-se divergências graves na economia mundial: desigualdade entre países, entre regiões e entre grupos sociais no acesso aos benefícios e ao conforto produzido pelas tecnologias, em termos de saúde e educação, entre outras questões de relevo. É fato que entre o período de 1981 e 2008 a pobreza absoluta caiu nos países periféricos, não obstante estes números serem ainda muito expressivos. Em 2008, 3/4 dos pobres no mundo, abaixo da linha de pobreza, viviam na Ásia, em que pesem o rápido crescimento econômico, a crescente participação da região na renda mundial e a industrialização.

É importante assinalar que a longa marcha das corporações internacionais, sua conquista de capilaridade internacional, fez com que uma parte significativa da industrialização dos periféricos tenha ocorrido sob a égide do capital internacional. São empresas que se beneficiam não apenas dos baixos salários nessas regiões, mas também dos aportes de financiamento dos estados receptores e ainda da remessa de lucros e dos pagamentos por uso de tecnologias exógenas. O economista Celso Furtado chamou a atenção para a questão:

Utilizando tecnologia amortizada, algumas vezes equipamentos também amortizados, e mobilizando capital local, as grandes empresas estão em condições de instalar indústrias na maior parte dos países de periferia, particularmente se essas indústrias se integram parcialmente com atividades de importação. ${ }^{37}$

As figuras abaixo ilustram alguns argumentos expostos, relativos à pobreza, à participação no comércio mundial de mercadorias e nas exportações de manufaturas, inclusive aquelas de valor agregado, entre os países em desenvolvimento.

36 Id. ibid., p. 176.

37 FURTADO, Celso (1983). O mito do desenvolvimento econômico. 6. ed. Rio de Janeiro: Paz e Terra. p. 45. 
Na primeira figura é patente a queda das curvas de pobreza e da indigência entre 1981 e 2008. Em percentagens a queda é acentuada, mas em valores numéricos, a queda da indigência é muito maior que a queda nominal da pobreza. Já na segunda figura, numa série temporal maior, percebe-se uma queda acentuada no quadro da participação no comércio mundial no período 1950-1974, que será interrompida a partir daí, para não mais deixar de crescer entre 1974 e 2010, salvo um breve período nos anos 1980-1985, quando ainda assim manteve patamares maiores que o período anterior de queda. Finalmente, a terceira figura evidencia a participação dos países em desenvolvimento com relação às exportações de manufaturas e aquelas de valor agregado entre 1950 e 2010, quando, a partir de 1970 a região passa a avançar ano a ano nas exportações de manufatura, o que também se credita a uma maior penetração das multinacionais em escala planetária. 
Figura 1: Tendências na Pobreza Absoluta em Países em Desenvolvimento 1981-2008.
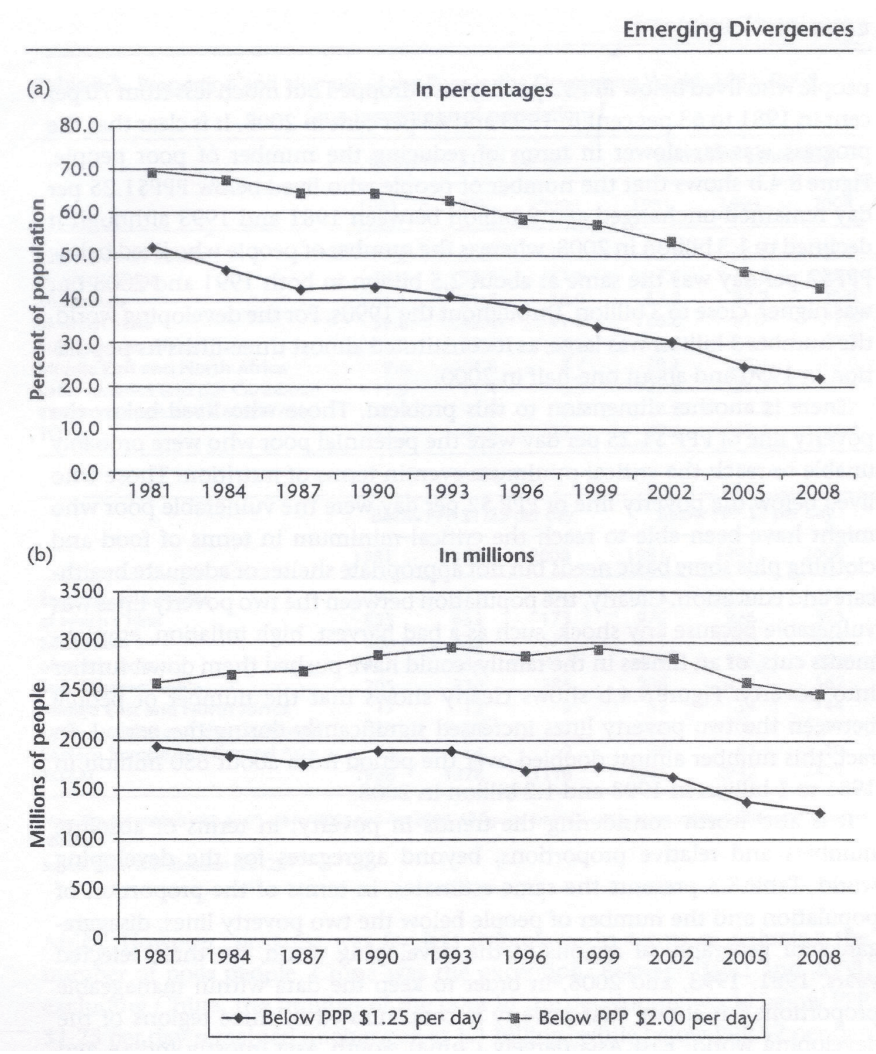

Fonte: Chen e Revallion (2012).

Figura 2: Participação dos países em desenvolvimento no comércio mundial de mercadorias 1950/2010.

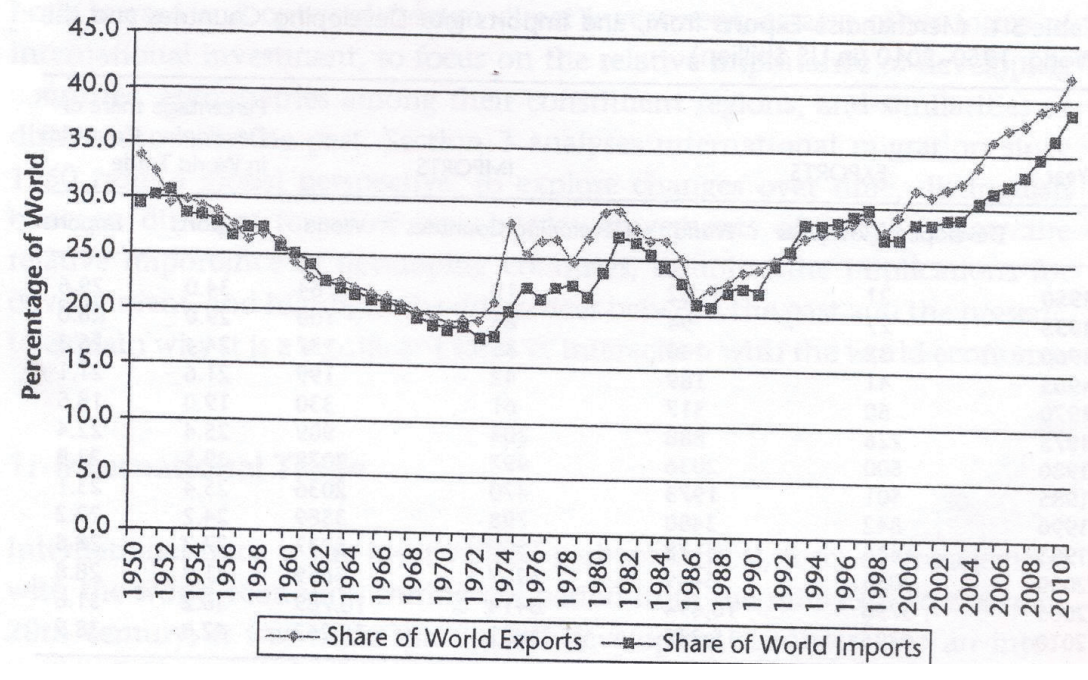

Fonte: United Nations, UnctadStat, baseado em UN International Trade Statistics. 
Figura 3: Participação dos países em desenvolvimento na exportação de manufaturas e manufaturas de valor agregado na economia mundial 1960-2010.

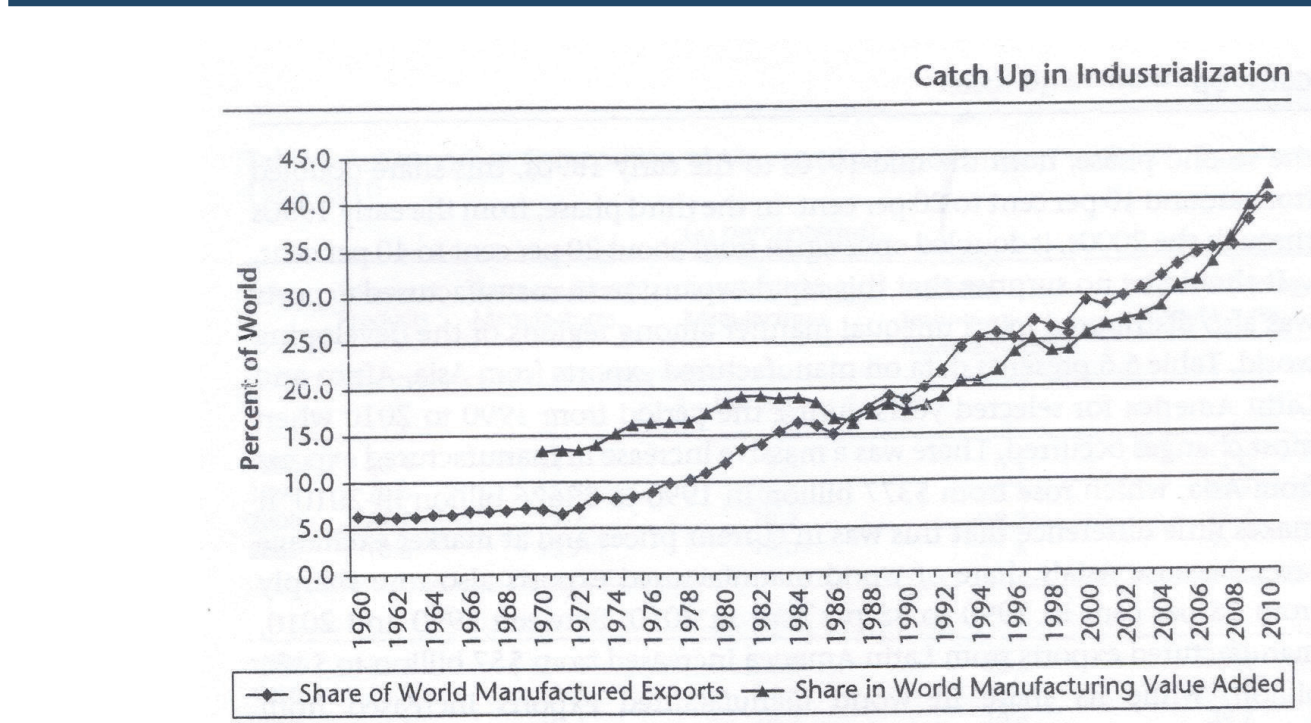

Fonte: United Nations.

\section{O contexto econômico global: crise, recessão e emprego, salários mundiais}

A crise global teve repercussões negativas importantes sobre os mercados de trabalho em muitas regiões do mundo, e a retomada ainda é incerta e será, muito provavelmente, duradoura. Sobretudo pelos efeitos nefastos que produziu. Em âmbito global os salários médios cresceram, mas a taxas inferiores às do período antes da crise. 0 presente Relatório Global sobre os Salários 2012/1338 evidencia, no entanto, que o impacto da crise nos salários está longe de ser uniforme.

Nas economias desenvolvidas, a crise provocou uma dupla queda nos salários: os salários médios reais caíram em 2008 e de novo em 2011; e em muitos destes países os salários registraram em 2012 um crescimento marginal.

Nos países emergentes, o crescimento dos salários foi, de modo geral, mais resiliente, com um forte crescimento na Ásia e mais modesto, mas apresentando ainda uma tendência positiva em África, na América Latina e nas Caraíbas.

38 OIT (2013). Relatório Global sobre os Salários 2012/13: salários e crescimento equitativo. Genève: ILO Publications. 
Na Europa de Leste e na Ásia Central, após a queda dos salários provocada pela crise em 2009, registrou-se um crescimento dos salários positivo, mas relativamente mais baixo.

Numa perspectiva de mais longo prazo, o relatório estima que os salários médios reais mensais quase duplicaram na Ásia entre 2000 e 2011, tendo aumentado 18\% em África, 15\% na América Latina e nas Caraíbas e 5\% nas economias desenvolvidas. Na Europa de Leste e na Ásia Central os salários quase triplicaram, embora partindo de uma base muito baixa na sequência do colapso econômico dos anos de 1990. Os dados disponíveis sobre salários no Oriente Médio são limitados, mas indicam que a baixa produtividade e a debilidade das instituições foram responsáveis pela estagnação dos salários durante a última década ${ }^{39}$.

Figura 4: Média Anual de Crescimento Econômico PIB Mundial - 1995-2012. (PIB a preços constantes)

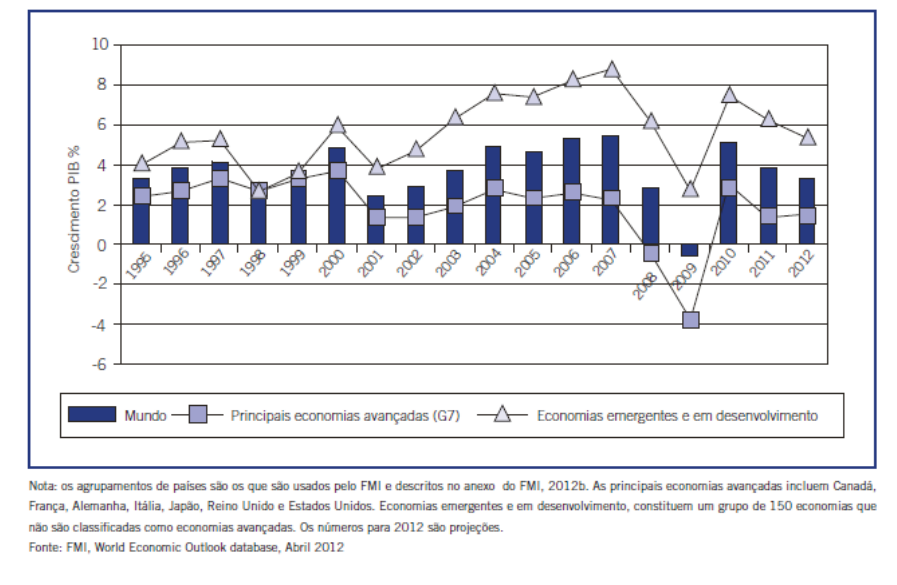

5.1 As taxas de crescimento econômico entre regiões mundiais

Após um período de forte crescimento econômico nos primeiros anos do século XXI, a economia mundial sofreu uma contração em 2009, como resultado da crise financeira e econômica global $\mathrm{O}$ impacto da crise foi sentido de formas muito diversas em todo o mundo. No grupo de países mais avançados, 2009 passou a ser visto como o ano da "Grande Recessão", a crise econômica mais grave desde a "Grande Depressão" dos anos de 1930. Embora a recuperação em 2010 tenha sido mais forte do que inicialmente previsto, a crise da dívida soberana e as várias medidas de austeridade que a

39 Id. ibid. 
acompanharam levaram a uma desaceleração significativa do crescimento subsequente, especialmente na Europa. O grupo de países emergentes e em desenvolvimento, pelo contrário, evitou uma recessão generalizada e conseguiu manter taxas de crescimento superiores às dos países avançados desde o ano 2000.

Figura 5: Estimativas e projeções de crescimento global e regional GDP, 2011-15 (porcentagem)

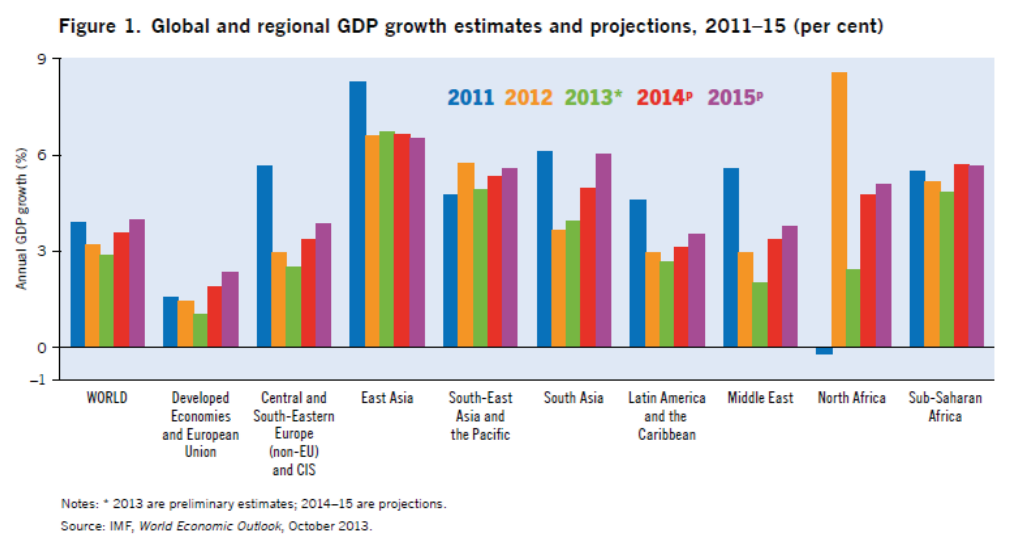

\subsection{A estagnação dos salários}

Em termos globais o crescimento dos salários médios reais manteve-se muito abaixo dos níveis pré-crise, apresentando valores negativos nas economias desenvolvidas, embora tenha permanecido elevado nas economias emergentes. Os salários médios mensais ajustados pela inflação - conhecidos como salários médios reais - cresceram globalmente 1,2\% em 2011, valor inferior aos 2,1\% em 2010 e aos 3\% em 2007. Face à sua dimensão e a um forte desempenho econômico, a China tem um grande peso neste cálculo global. Se não considerarmos a China, o crescimento dos salários médios reais globais foi de apenas 0,2\% em 2011, abaixo, portanto dos 1,3\% em 2010 e dos 2,3\% em 2007.

A OCDE observou que, durante o período de 1990 a 2009, o peso da remuneração do trabalho no rendimento nacional diminuiu em 26 dos 30 países avançados para os quais existem dados disponíveis, e calculou que o peso mediano do rendimento do trabalho no rendimento nacional em todos estes países caiu consideravelmente, de 66,1\% 
para $61,7 \%{ }^{40}$. Estas conclusões fazem eco das provas apresentadas no Relatório Global dos Salários de 2010/11 da OIT, o qual descreveu o declínio do peso dos salários na grande maioria dos países da OCDE desde $1980^{41}$.

\subsection{Diferenças salariais nos níveis regionais}

Apesar do crescimento significativo dos salários nas economias emergentes, as diferenças nos níveis salariais continuam a ser consideráveis. Nas Filipinas, um trabalhador da indústria transformadora ganhou menos de 1,40 USD por hora de trabalho. No Brasil, a remuneração paga numa base horária no setor foi de 5,40 USD; na Grécia, foi de 13 USD; nos Estados Unidos, de 23,30 USD; e na Dinamarca, de 34,80 USD (taxas de câmbio de 2010 arredondadas). Na Alemanha, a produtividade do trabalho aumentou em quase um quarto ao longo das últimas duas décadas, enquanto os salários reais mensais se mantiveram estáveis.

\subsection{A redução da participação dos trabalhadores no produto global}

Entre 1999 e 2011 a produtividade média do trabalho nas economias desenvolvidas aumentou mais que o dobro do salário médio. Nos Estados Unidos, a produtividade real horária do trabalho no setor empresarial não agrícola aumentou cerca de 85\% desde 1980, enquanto a remuneração horária real cresceu apenas cerca de 35\%. Na Alemanha, a produtividade do trabalho aumentou em quase um quarto ao longo das últimas duas décadas, enquanto os salários reais mensais se mantiveram estáveis.

A tendência global resultou numa mudança na distribuição do rendimento nacional, com uma diminuição da parte afeta aos rendimentos do trabalho ao passo que a parte do rendimento do capital aumentou na maioria dos países. Mesmo na China, um país onde os salários praticamente triplicaram na última década, o PIB cresceu a uma taxa mais rápida do que a massa salarial total - e, consequentemente o peso do rendimento do trabalho caiu.

40 OCDE (2012). OECD Employment Outlook 2012. Paris.

41 International Labour Office - ILO (2008). Global Wage Report 2008/09: Minimum wages and collective bargaining - Towards policy coherence. Geneva. Id. (2010). Global Wage Report 2010/11: Wage policies in times of crisis. Geneva. 


\section{Figura 6: Tendências de crescimento dos salários médios e produtividade do trabalho nas economias desenvolvidas (índice: 1999=100).}

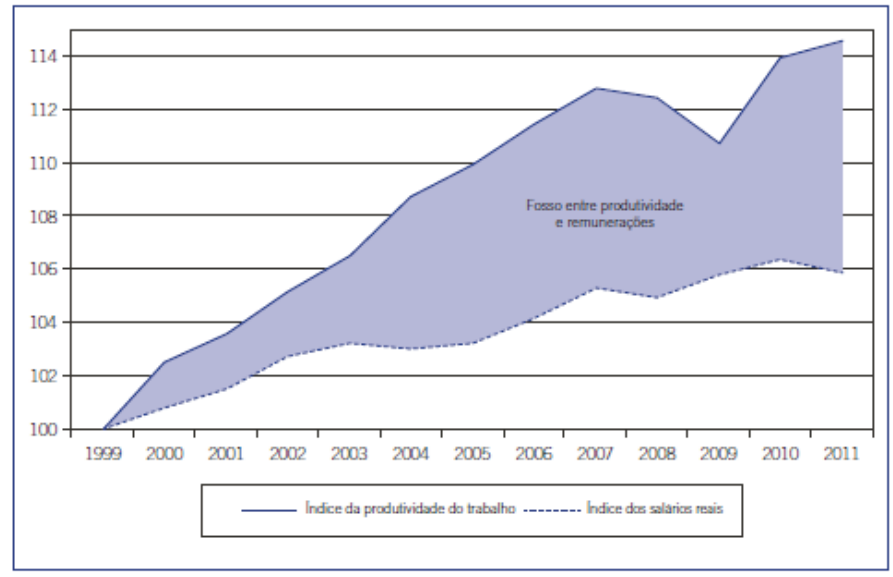

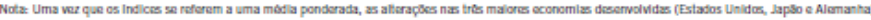

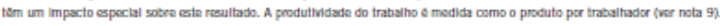

A queda no peso do rendimento do trabalho ficou a dever-se ao progresso tecnológico, à globalização do comércio, à expansão dos mercados financeiros e à diminuição da taxa de sindicalização, o que degradou o poder de negociação coletiva dos trabalhadores. A globalização financeira, em particular, pode ter desempenhado um papel mais relevante do que inicialmente se pensava.

O FMl42 concluiu que, entre 1980 e 2005, o peso do rendimento do trabalho dos trabalhadores não qualificados caiu nos Estados Unidos, Japão e Europa, mas aumentou para os trabalhadores qualificados com um nível de educação terciário ou superior (em 7,2 e 8\%, respectivamente).

Analisando um conjunto de quatro economias desenvolvidas (França, Alemanha, Reino Unido e Estados Unidos), Husson ${ }^{43}$ concluiu que durante o período 1987-2008 grande parte do excedente das empresas se destinou a reforçar os dividendos pagos aos acionistas. Calculou que na França o total de dividendos aumentou de 4\% da massa salarial total no início dos anos 1980 para 13\% em 2008. Curiosamente, no Reino Unido tanto a proporção dos pagamentos de dividendos das ações como o peso da remuneração do trabalho aumentaram, pelo que os dividendos mais elevados foram possíveis à custa da reduzida retenção de lucros. Nos Estados Unidos, três quartos do aumento do excedente bruto de exploração destinaram-se ao pagamento de dividendos.

42 International Monetary Fund - IMF (2007). The globalization of labor. In: World Economic Outlook, April 2007: Spillovers and cycles in the world economy. Washington, DC. pp. 161-192.

43 HUSSON, M. (2010). Le partage de la valeur ajoutée en Europe. In: La Revue de I'IRES, vol. 64, n. 1, pp. 47-91. 
Dada a maior concentração dos rendimentos do capital face aos do trabalho, o aumento dos dividendos, contribuiu quase sempre para o aumento da desigualdade de rendimento das famílias, em termos genéricos ${ }^{44}$.

Table 1. Global, regional and country-specific estimates and projections of the total unemployment rate, 2007-16 (percentage points)

\begin{tabular}{|c|c|c|c|c|c|c|}
\hline Country/region & 2007 & 2012 & $2013^{*}$ & $2014^{p}$ & $2015^{p}$ & $2016^{p}$ \\
\hline World & 5.5 & 6.0 & 6.0 & 6.1 & 6.1 & 6.1 \\
\hline G20 Economies & 5.1 & 5.7 & 5.8 & 5.8 & 5.8 & 5.8 \\
\hline G20 Advanced Economies & 5.7 & 8.4 & 8.4 & 8.4 & 8.3 & 8.1 \\
\hline G20 Emerging Economies & 4.9 & 4.9 & 5.0 & 5.1 & 5.1 & 5.1 \\
\hline Developed Economies and the European Union & 5.8 & 8.6 & 8.6 & 8.6 & 8.4 & 8.2 \\
\hline Australia & 4.4 & 5.2 & 5.6 & 5.7 & 5.7 & 5.8 \\
\hline Canada & 6.0 & 7.2 & 7.1 & 7.0 & 7.0 & 6.9 \\
\hline Japan & 3.9 & 4.3 & 4.1 & 4.0 & 4.0 & 4.0 \\
\hline United States & 4.7 & 8.2 & 7.5 & 7.2 & 6.8 & 6.4 \\
\hline European Union & 7.2 & 10.5 & 11.0 & 11.1 & 11.1 & 10.9 \\
\hline France & 8.0 & 9.9 & 10.5 & 10.9 & 10.8 & 10.7 \\
\hline Germany & 8.6 & 5.4 & 5.3 & 5.3 & 5.4 & 5.4 \\
\hline Italy & 6.1 & 10.7 & 12.2 & 12.6 & 12.7 & 12.7 \\
\hline United Kingdom & 5.4 & 8.0 & 7.5 & 7.3 & 7.2 & 7.1 \\
\hline Central and South-Eastern Europe (non-EU) and CIS & 8.2 & 8.0 & 8.2 & 8.3 & 8.2 & 8.2 \\
\hline Russian Federation & 6.0 & 5.5 & 5.8 & 5.8 & 5.8 & 5.8 \\
\hline Turkey & 10.3 & 9.2 & 9.9 & 10.0 & 9.7 & 9.6 \\
\hline Middle East & 10.2 & 10.9 & 10.9 & 11.0 & 10.9 & 10.8 \\
\hline North Africa & 11.1 & 12.1 & 12.2 & 12.2 & 12.1 & 12.1 \\
\hline Sub-Saharan Africa & 7.5 & 7.6 & 7.6 & 7.6 & 7.5 & 7.5 \\
\hline South Africa & 22.3 & 25.0 & 25.3 & 25.2 & 25.1 & 25.1 \\
\hline Latin America and the Caribbean & 6.9 & 6.6 & 6.5 & 6.5 & 6.5 & 6.5 \\
\hline Argentina & 8.5 & 7.2 & 7.3 & 7.4 & 7.4 & 7.3 \\
\hline Brazil & 8.1 & 6.9 & 6.7 & 6.6 & 6.5 & 6.5 \\
\hline Mexico & 3.4 & 4.9 & 5.0 & 4.9 & 4.8 & 4.7 \\
\hline East Asia & 3.8 & 4.4 & 4.5 & 4.7 & 4.8 & 4.9 \\
\hline Republic of Korea & 3.2 & 3.2 & 3.2 & 3.3 & 3.3 & 3.4 \\
\hline South-East Asia and the Pacific & 5.5 & 4.1 & 4.2 & 4.3 & 4.3 & 4.3 \\
\hline Indonesia & 9.1 & 6.1 & 6.0 & 6.0 & 6.0 & 6.0 \\
\hline South Asia & 4.1 & 3.9 & 4.0 & 4.0 & 4.1 & 4.1 \\
\hline
\end{tabular}

Notes: * 2013 are preliminary estimates; 2014-18 are projections. Estimates and projections for individual G20 countries are shown only when they are based on a minimum number of actual data points. Figures might differ from national estimates or those published in the Panorama Laboral (ILO, 2013a), mainly as a result of differences in geographical coverage.

Source: ILO, Trends Econometric Models, October 2013.

\section{$6 \quad$ O Brasil: desafios e oportunidades}

Concluo esse já longo artigo estabelecendo algumas reflexões sobre o Brasil.

O economista e ex-presidente do IPEA, Márcio Pochman ${ }^{45}$ constata que justamente o pior desempenho econômico e social ocorreu durante as décadas de 1980 e 1990,

44 Organization for Economic Co-operation and Development - OECD (2011). Divided we stand: Why inequality keeps rising. Paris. ROINE, J.; WALDENSTRÖM, D. (2012). On the role of capital gains in Swedish income inequality. In: Review of Income and Wealth, vol. 58, n. 3, pp. 569-587.

45 POCHMAN, Márcio (2009). A tarefa dos progressistas. In: <http://partisanrs.blogspot.com.br/2009/05/marciopochmann-tarefa-dos.html>. Acessado em 30/1/2014. 
quando a renda per capita manteve-se praticamente estagnada, a distribuição da renda nacional tornou-se ainda mais concentrada, a inflação atingiu patamares inaceitáveis, o endividamento público era crescente e a inserção internacional foi regressiva. Tudo isso em decorrência das políticas de ajuste definidas pelo FMl e acatadas pelos governos de então.

Esse quadro passou a ser alterado a partir de 2004, quando o conjunto dos indicadores econômicos e sociais brasileiros passou a confirmar o cenário muito diferente daquele verificado nas décadas anteriores. $\mathrm{O}$ endividamento do setor público passou a refluir significativamente (de mais de 50\% para próximo de 1/3 do produto nacional), acompanhado por estável índice do custo de vida da população, pelo reforço das relações externas e satisfatória expansão econômica, mais de duas vezes superior à verificada nos anos 1990, por exemplo. As implicações disso para o país não tardaram a se manifestar em termos da considerável ampliação do emprego formal e da mobilidade social, bem como pela queda no desemprego, na pobreza e na desigualdade de renda.

Em síntese, a combinação positiva do crescimento econômico com a inclusão social potencializada por corretas políticas públicas de incorporação de mais de vinte miIhões de brasileiros ao padrão de consumo de massa, o que pode ser verificado pelo gráfico a seguir.

Renda: Participação de salários no PIB (\%): 1995-2010 - Brasil

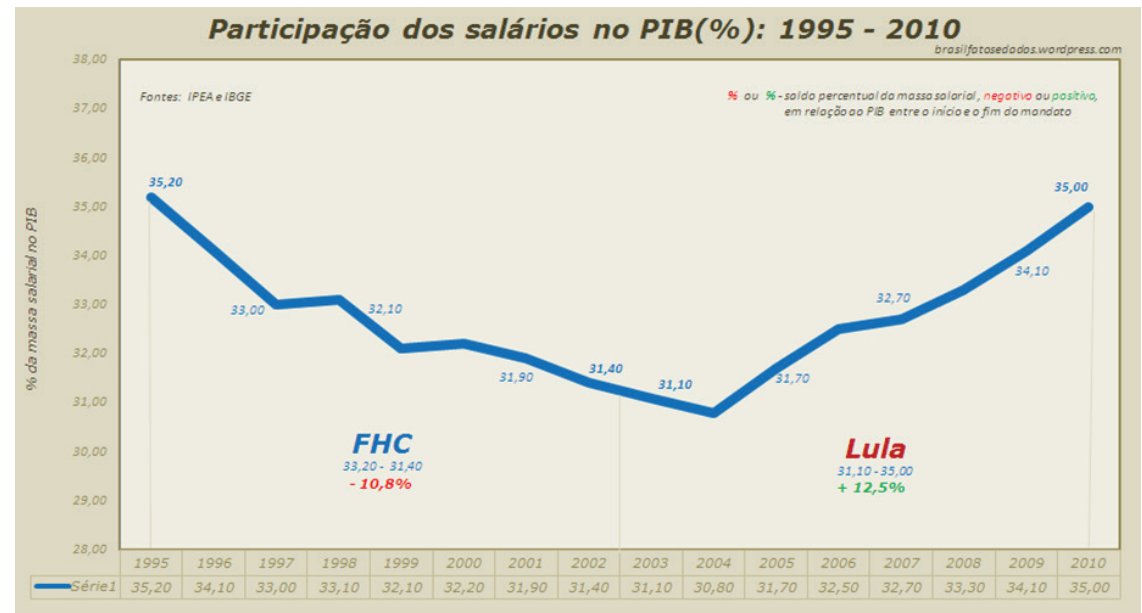

Fonte: Publicado em 01/10/2010 por brasilfatosedados. 
Após a crise que se instala e propaga a partir da economia dos Estados Unidos em 2008, diz o economista46 que para o Brasil, três principais vetores de transmissão da crise externa se destacam. O primeiro refere-se à drástica contenção do crédito internacional, que atingiu fortemente o setor produtivo doméstico, especialmente as empresas produtoras de mercadorias de maior valor unitário e dependentes de financiamentos (bens de consumo durável e de capitais). O segundo vetor está relacionado à retração do comércio externo, que impacta diretamente parcela do setor produtivo exportador. O terceiro vetor é decorrente das decisões das matrizes das grandes corporações transnacionais, responsáveis pelo reposicionamento mais contido das filiais em operação no país. De todo modo, o Brasil tem um conjunto de problemas estruturais que precisam ser enfrentados, ao custo de perdermos os avanços que foram consolidados a partir de 2004. São eles: a pobreza rural e urbana; a concentração fundiária; a ainda imensa concentração de renda; os desníveis regionais acentuados; a baixa escolaridade da maioria da população; os gargalos de infraestrutura; a debilidade de nosso sistema de pesquisa e desenvolvimento; a corrupção política; a baixa qualificação da mão de obra; um processo insidioso de desindustrialização e de reprimarização da economia; os problemas habitacionais e de mobilidade urbana.

- Oportunidades: democracia consolidada; liderança na América do Sul; pacifismo nas fronteiras; pacifismo interno; crescimento com inclusão; redução da pobreza e analfabetismo; políticas Sul-Sul bem construídas.

- Questão agrária: concentração fundiária e agrobusiness - pobreza rural e desemprego no campo;

- Concentração de renda;

- Reprimarização da economia;

- Dívida pública: 42\% do orçamento geral da União

- Dívida pública em 2013: R\$2,02 trilhões

- Saúde e educação juntos: apenas 7,06\%

- Déficit de 8 milhões de moradias;

- Fortes desigualdades regionais.

A peça orçamentária de 2013 reserva 900 bilhões de reais (correspondente a 42\% do orçamento geral da União) para o pagamento de juros e amortizações da dívida

$46 \quad$ Id. ibid. 
pública, enquanto estão previstos, por exemplo, R\$ 71,7 bilhões para educação, $\mathrm{R} \$ 87,7$ bilhões para a saúde e $\mathrm{R} \$ 5$ bilhões para a reforma agrária.

A distribuição do investimento estrangeiro direto por setores no Brasil mudou significativamente entre 2000 e 2009.

De fato, nossa carga tributária saltou de 26,7\% do PIB em 1996 para 35,9\% do PIB em 2012. A despeito disto, o investimento público federal nos últimos anos tem estado estagnado em níveis próximos a apenas 1\% do PIB.

O Brasil, que pouco avançou na democratização da propriedade segue mantendo apenas 6\% de toda sua da população com posse dos meios de produção ${ }^{47}$.

Em 2000, o setor terciário era o principal receptor de IED, recebendo 72\% do total.

Em 2009, a participação do IED mudou de cenário: o investimento do terciário diminuiu para 43\%. Aumentou a participação dos setores primário e secundário, que eram 3\% e 15\%, respectivamente em 2000, e passaram, em 2009, para 14,5\% e 43\%,

\section{Crescimento médio anual dos salários reais no Brasil 2006-2011}

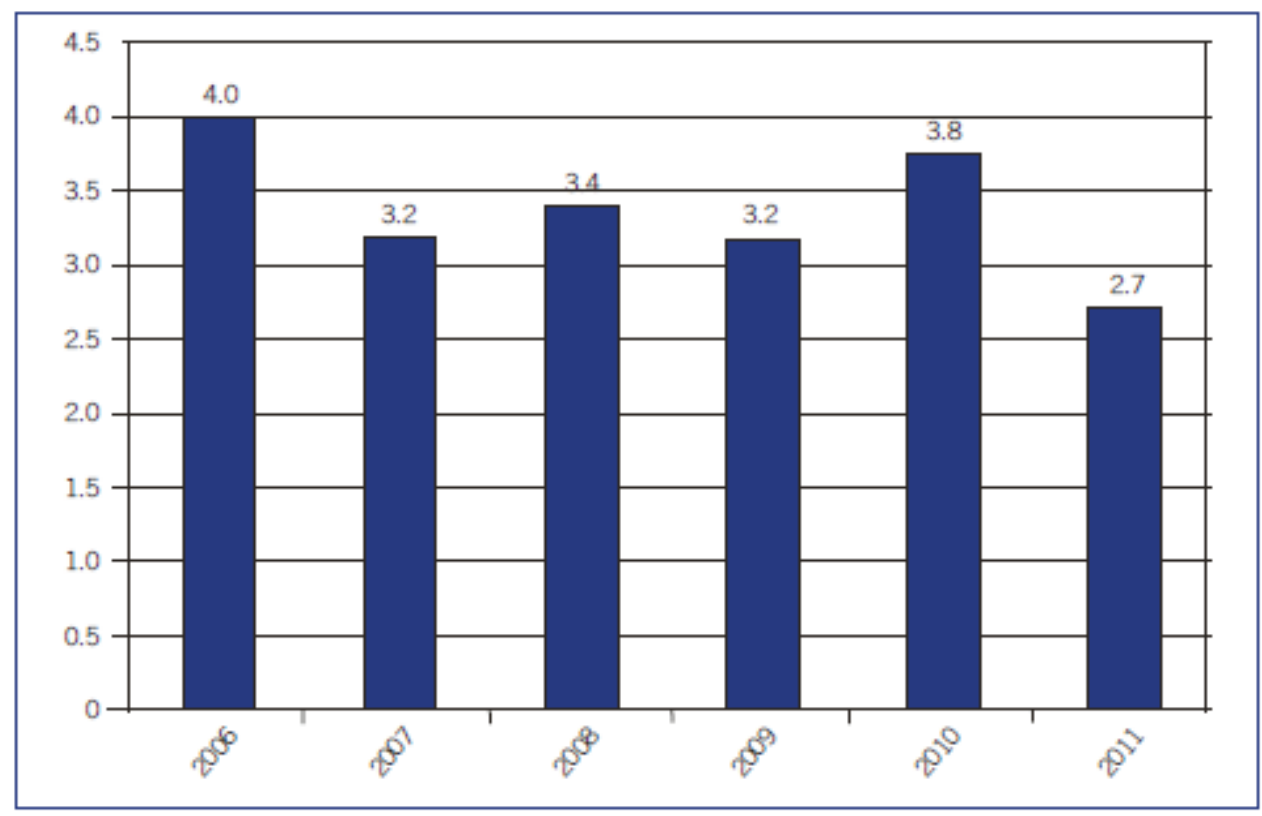

Noka. Para cobertura e metodalogla ver Anewo I

Fonte: ILO Global Wage Datatase.

$47 \quad$ AMORIM, R. et al (2009). Os proprietários no Brasil. São Paulo: Cortez. 


\section{Referências:}

AMORIM, R. et al (2009). Os proprietários no Brasil. São Paulo: Cortez.

BOURDIEU, Pierre (1998). Contrafogos. Táticas para enfrentar a invasão neoliberal. Rio de Janeiro: Zahar. pp. 9-19.

CHEN, Shaohua; RAVALLION, Martin (2012). More Relatively-Poor People in a Less Absolutely-Poor World. Policy research Working paper 6114, Washington, DC: The World Bank.

CHESNAIS, François (2011). Aux racines de la crise économique mondiale. In: Carré Rouge, n. 46, décembre, pp. 7-17.

COSTA LIMA, Marcos (2014). A economia política de François Chesnais: ciência eluta. In: CASSIOLATO, José; MATOS, Marcelo; LASTRES, Helena (orgs.): Desenvolvimento e Mundialização. O Brasil e o pensamento de François Chesnais. Rio de Janeiro: E-papers. (2012). O Brasil e os BRICS e a agenda internacional. In: FUNAG (org.). O Brasil e os Brics e a agenda internacional. Brasília: Funag. p.162.

(2011), Região \& desenvolvimento no capitalismo contemporâneo. São Paulo: UNESP, pp. $1-2$.

FURTADO, Celso (1983). O mito do desenvolvimento econômico. 6. ed. Rio de Janeiro: Paz e Terra. p. 45.

GILL, Louis (2012). Aprés cinq ans de crise. Un état des lieux sommaire. In: Carré Rouge, n. 47été.

HARVEY, David (2005). The New Imperialism. Oxford University Press. pp. 91-93.

HUSSON, M. (2010). Le partage de la valeur ajoutée en Europe. In: La Revue de I'IRES, vol. 64, n. 1, pp. 47-91.

INTERNATIONAL LABOUR OFFICE - ILO (2014). Global employment trends 2014: Risk of a jobless recovery? Geneva: International Labour Office. (2010). Global Wage Report 2010/11: Wage policies in times of crisis. Geneva: International Labour Office.

(2008). Global Wage Report 2008/09: Minimum wages and collective bargaining Towards policy coherence. Geneva: International Labour Office.

INTERNATIONAL MONETARY FUND - IMF (2007). The globalization of labor. In: World Economic Outlook, April2007: Spillovers and cycles in the world economy. Washington, DC. pp. 161-192. 
KRUGMAN, Paul (2010). A consciência de um liberal. Rio de Janeiro: Record.

LAZONICK, W.; O'SULLIVAN, M. (2000). Maximising shareholder value: A new ideology for corporate governance. In: Economy and Society, vol. 29, n. 1, pp. 13-35.

MADDISON, Angus (1983). A comparison of levels of GDP per capita in Develop and Developing Countries, 1700-1980. In: Journal of Economic History, 43, pp. 27-41.

NAYYAR, Deepak (2013), Catch UP. Developing Countries in the World economy. Oxford University Press.

(2009). Developing Countries in the World Economy: The Future in the Past? In: WIDER Annual Lecture 12, Helsinki: UNU-WIDER.

O'CONNOR, James (1976). The fiscal Crises of the State. New York: St Martin's Press.

ORGANIZATION FOR ECONOMIC CO-OPERATION AND DEVELOPMENT - OECD (2012a). Inequality in labour income: What are its drivers and how can it be reduced? OECD Economic Department Policy Notes n. 8, Paris. (2012b). OECD Employment Outlook 2012. Paris. (2011). Divided we stand: Why inequality keeps rising. Paris.

OIT (2013). Relatório Global sobre os Salários 2012/13: salários e crescimento equitativo. Genève: ILO Publications.

PALLEY, Thomas I (2013). Gattopardo economics. The crisis and the mainstream response of change that keeps things the same. In: Working Paper, april, n. 112. Macroeconomic Police Institute.

POCHMAN, Márcio (2009). A tarefa dos progressistas. In: <http://partisanrs.blogspot.com. br/2009/05/marcio-pochmann-tarefa-dos.html>. Acessado em: 30/1/2014.

POLANYI, Karl (2000). A grande transformação. As origens da nossa época. Rio de Janeiro: Contraponto.

PREBISH, Raúl (1968). Dinâmica do desenvolvimento latino-americano. Rio de Janeiro: Editora Fundo de Cultura. pp. 94-196.

REICH, Robert (2010). The Root of Economic Fragility and Political Anger. In: Huffington Post, 13 July.

RODRIK, Dani (2012). O renascer do Estado-nação. In: Project Syndicate, 13/03/2012.

ROINE, J.; WALDENSTRÖM, D. (2012). On the role of capital gains in Swedish income inequality. In: Review of Income and Wealth, vol. 58, n. 3, pp. 569-587.

SERFATI, Claude (2013). The new Configurations of Capital Class. Socialist register, pp. 138-161. 
STIGLITZ, Joseph E. (2012). The Price of Inequality. How today's divided society endangers our future. New York: W.W.Norton \& Company. pp. ix; 2-3.

STOCKMAN, David A. (2013). The Great Deformation. The Corruption of Capitalism in America. New York: Public Affairs Book.

(2013). State-Wrecked: the corruption of capitalism in America. In: The New York Times, 30/03/2013, pp. 15-16; 59.

Recebido: 12/6/2014

Aceito: 25/6/2014 